\title{
The 2012 Mayan calendar prophecies in the context of the western millenarian tradition
}

\author{
Nicholas Campion \\ Sophia Centre for the Study of Cosmology in Culture, \\ School of Archaeology, History and Anthropology, \\ University of Wales Trinity Saint David, \\ Lampeter, Ceredigion, Wales, SA48 7ED, UK \\ email: ncampion@tsd.ac.uk
}

\begin{abstract}
The 2012 Mayan calendar prophecies have attracted considerable popular interest, thought little academic attention. Following the papers presented in the 2012 Session at the conference, I suggest that the '2012 phenomenon' is the latest in a historic series of millenarian movements that form an established part of Christian culture. The 2012 prophecies, while Christian in neither tone nor affiliation, may be contextualised within secularised versions of western millenarianism as a whole. My purpose is to create a framework for analysis, placing the 2012 phenomenon within a wider cultural milieu and analysing its texts. I suggest that Karl Popper's paradoxical theory of historicism and activism, and the model of pre- versus post-millenarianism, may both provide means of analysing competing forms of 2012 prophecy.
\end{abstract}

Keywords. 2012 Maya prophecy, millenarianism, New Age, historicism

\section{Introduction}

The papers presented at this session have demonstrated that the apocalyptic prophecies associated with the supposed end of the Maya long-count in December 2012 may be based on an exaggerated reading of the relevant Maya inscriptions and misunderstandings of Maya calendar calculations (van Stone), together with an inflation of the apocalyptic content of Maya thought in the scholarly literature (Hoopes), both of which have in turn encouraged the wider counter-cultural Maya Prophecy Movement (MPM). We may call the MPM counter-cultural in the sense that its view of the future posits a challenge to the survival of human culture as a whole. It is also, I argue, millenarian.

\section{Millenarianism in the western tradition}

The word millenarianism, first used in the fifth century CE by St. Augustine (1972: XX.7), is derived from the Latin millennium, a thousand, and refers to the Persian (Boyce 1987) and, subsequently, Christian belief that world history is divided into periods of a thousand years (Cohn 1957; Campion 1994). Christian millenarianism has roots in Mesopotamian, classical Greek and Jewish thought, but the most powerful works are those within the Christian milieu. The classic text of Christian millenarianism is the Revelation of St. John, which sets out a historical template in which moral collapse climaxes in political and military strife, accompanied by the parousia (literally 'arrival' or 'presence'), that is Christ's return. In the first century CE this event was believed to be imminent (Mark 13.30, Revelation 22.12).

There is an additional terminology associated with millenarianism. From apocalypse, the Greek for revelation, is derived the word 'apocalyptic' to describe the vision of the end of the world that was revealed to St. John. The terms millenarian and apocalyptic 
tend to be used interchangeably. Although the term millenarian has strictly Christian connotations, it may be applied to all beliefs that the world is about to enter a major new phase. In its looser definition, therefore, any political or religious movement or ideology that expects, prophesies, or fights for, an imminent historical crisis and return to, or inauguration of, a golden age or state of purity, may be described as both millenarian (Robbins \& Palmer 1997; Hall et al. 2000; Stone 2000) and apocalyptic. I suggest that the MPM is apocalyptic both in the colloquial sense that in many (but not all forms) it predicts a violent upheaval, and in the strict sense that its knowledge of the future is gleaned from revelation, even if primarily as revealed to the Maya.

The main features of millenarian thought may be summarised as follows (Campion 2004: 33-38): catastrophism, a preoccupation with moral collapse, alienation from nature or the divine, nostalgia for a lost golden-age, a belief in historical time as cyclical or, in its broad themes, repetitive, and the application of astrological/astronomical factors to the timing of prophetic events. We should also bring modern New Age culture into consideration as a species of millenarian thought (Hanegraaff 1996: 96, 98-103), based as it is on the prophecy of an imminent age of enhanced spirituality, which is due to begin when the vernal point enters the constellation or zodiac sign (the definitions vary) of Aquarius: that the prophecy is linked to a measurable astronomical event is seen as evidence of its veracity. In addition, New Age culture possesses the following characteristics (Campion 2004: 76-78): an emphasis on education, personal transformation and spiritual growth.

Both Christian millenarianism and New Age prophecy draw their legitimacy from astronomical/astrological timing, and a form of cultural astronomy in which celestial motions are seen either as divinely-inspired omens, or as evidence of the unfolding of a mathematically-ordered cosmos, in which historical crises coincide with powerful planetary aspects. The use of celestial omens in order to predict the coming crisis was encouraged by texts such as Mark 13.24-26 ("in those days, after that tribulation, the sun will be darkened, and the moon will not give its light, and the stars will be falling from heaven") while, in medieval and Renaissance Europe, the notion of a mathematically regulated universe prompting historical upheaval was tied to the cycle of Jupiter-Saturn conjunctions, following the Persian model, recorded in the eighth century by Abu Ma`shar (Abu Ma`shar 2000: I.16; Campion 1994: 354-359).

The MPM follows the following characteristics, established in Jose Argüelles' seminal text, The Mayan Factor (1987): it envisages physical upheaval coinciding with an exact astronomical and calendrical alignment, followed by an era of enhanced spiritual awareness. So successfully did Argüelles' work capture the New Age imagination that the previous astronomical basis for forecasting the coming of the future age, based on precession of the equinoxes and the beginning of the Age of Aquarius, has now been largely superseded. The favoured application of precession in the MPM is the coming conjunction between the December solstice sun and the Galactic equator (Jenkins 1998).

\section{The nature of the MPM}

The MPM is clearly of cultural significance as a contemporary form of a two-millenniaold tradition of millenarian thought in western culture: a simple Google search for 'Mayan Prophecy 2012' yields 2.8 million results, with thousands of protagonists eager to make their views heard. There are many questions one can ask about the MPM's nature, whether of its religious content, political ideologies or sociological context. I am concerned with its statements about the nature of history and would like to ask the following questions about it, adapted from previous discussions concerning millenarianism and New Age culture. 


\subsection{Does the MPM constitute a philosophy of history?}

In that it makes an astrologically-based prophecy about the future direction of history, the MPM may confirm what Eugenio Garin, writing of Renaissance astrology, considered to be "a precise philosophy of history based on a conception of the universe, and characterised by a consistent naturalism and a rigid determinism" (Garin 1976: 16). Keith Thomas also considered whether astrology had a function in the development of historical thought. He concluded that it did, adding that the sociological world view has at least partial roots in the astrological, and writing that during the Italian Renaissance astrological doctrines about the recurrence of planetary conjunctions had helped both to form the concept of a historical period and offer a model of social development (Thomas 1980: 386-387). The historical models identified by Garin and Thomas in Renaissance historiography can be traced back to Plato's statement in the Timaeus concerning the role of planetary and stellar motion in world history (Plato 1931: 39D): "The complete number of Time fulfils the Complete year when all the eight circuits with their relative speeds, finish together and come to a head, when measured by the revolution of the Same and the Similarly-moving." MPM historiography, in that it postulates an unfolding order in which celestial and terrestrial events are inextricably linked, is therefore identifiably Platonic.

\subsection{Are there parallels with other modern forms of millenarian thought?}

It has been persuasively argued that there is a direct continuity between ancient and modern eschatology. Cohn (1970: 108-109) argued for a close relationship between ancient, medieval and modern millenarianism and hence that Marxism and Nazism, the most powerful political ideologies of twentieth-century Europe, were secular forms of millenarianism: both assumed that history follows patterns that are broadly predetermined and punctuated by major upheavals or cataclysms that, in turn, result in a new golden-age. For Schwartz (1980) and Godwin (1994), the revolutionary and esoteric millenarianism of the late eighteenth and early nineteenth centuries provided the link between the medieval Christian world on the one hand, and the modern, secular, world on the other. The most pervasive form of secular millenarianism in the modern world, though, according to Baillie (1951: 64-65), is belief in progress, which was first set out by the Marquis de Condorcet in 1795 in his optimistic view that the condition of the world must necessarily improve as time passes and that any future age must, in principle, be qualitatively an improvement on any past age (Condorcet 1955). Such progressive philosophy is central to the core New Age belief that the coming era will inevitably be preferably to the present. Baillie argued that progress theory evolved directly out of Jewish and Christian millenarianism's message of hope that a new world will be born. Bury (1932: 1-36) made a similar argument, but proposed Platonic apocalyptic thought as the basis of progress theory.

\subsection{Does the MPM encourage wider cultural activity?}

Karl Popper's theory of historicism and activism (Popper 1957), which was directed at an understanding of the millenarian components of Platonic and Marxist historical theory, provides a framework for understanding millenarianism's political and social functions. Historicism, for Popper, was the belief that the events of history were arranged into patterns and regulated by laws according to a deeper, unfolding purpose. Popper's theory of historicism was at odds with the conventional theory associated with the anthropologist Franz Boas, in which historicism was considered to be the belief that history should be understood through local and complex processes, rather than universal causes (Boas 1904: 522; Stocking 1966: 871). Popper argued that historicist theories have two central characteristics. Firstly, they take it for granted that historical change develops according 
to underlying laws, which suggests in turn a broadly predetermined pattern and a purposeful goal. Secondly, while history is predetermined, human beings paradoxically possess the capacity to make free choices. The only free choice to be made in relation to history, though, is to help it on its way and serve its greater purpose. This active participation, Popper termed activism. Thus, Christian activism demands that the faithful evangelise the gospels to prepare for the second coming, while twentieth-century Marxism required the politically aware to form a revolutionary vanguard and prepare for the revolution. The New Age movement, it may be argued, exhibits the same paradox: while, in the form of the Age of Aquarius, the New Age is inevitable, just as the movement of the vernal point into Aquarius must happen, still it is necessary to prepare for the Age. As Louis Le Roy wrote, in relation to Platonic millenarianism, "The best thing is to wisely help destiny run its course" (Le Roy 1594: 11). The seminal activist event in the MPM was the so-called Harmonic Convergence of 16th-17th August 1987 which was intended, through a mass, ritual meditation to avert any dangerous implications of the coming calendrical event. Calls for participatory engagement in order to encourage the coming historical shift are widespread within the MPM. Calleman (2011: 105), for example, calls for a 'massive participation' in a public programme that encourages the 'shift to consciousness of the ninth wave', in order to take advantage of 'the last chance that human beings will have to truly align themselves with the cosmic plan', and will require involvement in social media, funding initiatives and mass events.

\subsection{Is the MPM violent or peaceful?}

One framework for understanding whether millenarian prophecies are peaceful or violent was suggested by Desroche (1979: 93-94), who identified two forms of Christian millenarianism. The first, 'premillenarianism', or 'premillenialism' (Wessinger 1997: 4849), argues that Christ will come before the millennium, typically accompanied by the violent upheavals prophesied in Revelation. This may also be commonly referred to as catastrophic millenarianism. The second form, postmillennialism, or 'progressive' millenarianism (Wessinger 1997: 50-51) assumes that the "kingdom of God is progressively installed by an evolutive process" (Desroche 1979: 93), which therefore removes any need for a violent transition. We see both forms of millenarianism in MPM literature. For example, Patrick Geryl (2011) is pre-millennial, predicting that

"In 2012 the next polar reversal will take place on earth. This means that the North

Pole will be changed into the South Pole. Scientifically this can only be explained by the fact that the earth will start rotating in the opposite direction, together with a huge disaster of unknown proportions. In my books I reveal the immense cataclysm that is going to torment the earth in the near future."

Eden Sky (2011), though, is post-millennial, and appropriates the transformational language and Popperian activism of so much New Age discourse:

"First things first - rather than preparing for the future event down the road, let's notice how we are participating in the moment. Rather than focusing on an imaginary disaster, we need to realise that we are already in the midst of the planetary transformation."

\subsection{What is the role of astrology?}

Hilary Carey posed two questions in her study of medieval astrology (1992); firstly what motivates and sustains belief in astrology and, secondly, what intellectual function does it serve? A possible answer was suggested by Karl Popper who noted that astrology's practice is based around the activist paradox that, although the future is predetermined, knowledge of what is to come enables human beings to amend it. He argued that

"Astrology, it should be realised, shares with historicism the belief in a predeterminate destiny which can be predicted: and it shares with some important versions of historicism 
(especially with Platonism and Marxism) the belief that, notwithstanding the possibility of predicting the future, we have some influence upon it, especially if we know what is coming... All astrology, for instance, involves the apparently somewhat contradictory conception that the knowledge of our fate may help us to influence this fate." (Popper 1986: I.210, 244)

In Popper's scheme, astrology is sustained by the need for security and order in a world beset by potentially threatening change and instability, a fact on which academics and critics agree with astrologers working within the theosophical tradition, although the latter would add the quest for personal meaning as an important additional motive. In the astrological milieu, security is to be obtained through the manipulation of a future which, once forecast, can be turned to human advantage. The fundamental political-astrological belief that the futures of heavenly cosmos and terrestrial state are equally fated on the one hand, can be contrasted with astrology's attempt, via the detailed examination of horoscopes to manipulate the future, on the other. It is therefore the astrologer's task to enhance human freedom of choice as much as possible within the limits set by historical and cosmic law. Carey (1992: 3-5) suggested a similar conclusion. Citing Malinowski's theory (1954: 25-36) that one of magic's primary functions is to provide a means of influencing forces and events normally outside human control, she raises the question as to whether astrological forecasting, combined with the rituals which often accompanied it, may be seen as ways of intervening in historical order. Astrology's function, as a particular application of activist divination to the cosmic state, may therefore be understood within the differing frameworks of competing historicist narratives. If the underlying purpose of historicism is to control change then astrology, within the terms set by Karl Popper, may be seen, within the millenarian framework, as a principal activist discipline. In this sense the astronomical features of the MPM drive its activist programme, the assurance that the astronomical patterns 'will' happen, providing validation for the wider prophecy.

\section{Conclusion}

Given that no millennial movement necessarily includes the same combination of beliefs in the same balance as any other, it is often impossible to define such movements, except by acknowledging the paradoxes they contain and the tensions these generate. In addition, like any other cultural, social or political force, millenarianism constantly adapts to changing circumstances. As Schwartz (1980: 6) puts it, "millenarian moods and perceptions change as believers battle to keep their footing". Moreover, as Desroche (1979: 99) argues, "the millenarian tradition is cumulative", with later forms both arising out of earlier ones and looking back to them for authority.

As a millenarian phenomenon, the MPM may therefore be seen to conform to a longstanding strand of ideas in western culture that emerges from roots in classical Platonism and Judaism, is fundamental to Christianity, and has secular forms in Marxism, Nazism and the theory of Progress, as well as New Age culture. I suggest that a potentially useful path to examining the MPM is in terms of an established cosmological philosophy of history, justified by Plato, identified in the Renaissance by Garin and defined by Popper as historicist and activist. Having confirmed that the prophecies have no basis in Maya calendrics, the next step, following Popper, is to pose such questions as "what forms of political or social action do the prophecies encourage?', applying methodologies from history, sociology and anthropology. In addition, as a contemporary 'cultural astronomy', the MPM's existence in the modern west is a vivid demonstration that cosmologies that flourish in the modern west may not be substantially different from those normally categorised as 'non-western' and 'pre-modern'. 


\section{References}

Abu Ma`shar 2000, On Historical Astrology: the Book of Religions and Dynasties (On the Great Conjunctions) (2 vols), ed. \& transl. K. Yamamoto \& C. Burnett, E. J. Brill, Leiden.

Argüelles, J. 1987, The Mayan Factor: Path Beyond Technology, Bear \& Co., Santa Fe.

Augustine 1972, City of God, transl. H. Bettenson, Penguin, Harmondsworth.

Baillie, J. 1951, The Belief in Progress, Oxford University Press, London.

Boas, F. 1904, Some traits of primitive culture. Journal of American Folklore 17, 243-254.

Boyce, M. 1987, Zoroastrians: their Religious Beliefs and Practices, Routledge \& Kegan Paul, London \& New York.

Bury, J. B. 1932, The Idea of Progress: an Inquiry into its Origin and Growth, Macmillan, New York.

Calleman, C. 2011, Creating the intention for the unity consciousness of the ninth wave of the Mayan calendar. In J. Young (ed.), 2013: The Beginning is Here!, O Books, Winchester, pp. $98-108$.

Campion, N. 1994, The Great Year: Astrology, Millenarianism and History in the Western Tradition, Penguin, London.

Campion, N. 2004, Prophecy, Cosmology and the New Age Movement: the Extent and Nature of Contemporary Belief in Astrology, PhD thesis, University of the West of England, Bristol.

Carey, H. 1992, Courting Disaster: Astrology at the English Court and University in the Later Middle Ages, MacMillan, London.

Cohn, N. 1970, The Pursuit of the Millennium. Revolutionary Millenarians and Mystical Anarchists of the Middle Ages, Oxford University Press, London \& New York.

Condorcet, Marquis de 1955, Sketch for a Historical Picture of the Progress of the Human Mind, Paris 1795, transl. J. Barraclough, Weidenfeld \& Nicholson, London.

Desroche, H. 1979, The Sociology of Hope, Routledge \& Kegan Paul, London.

Garin, E. 1976, Italian Humanism, Greenwood Press, Santa Barbara.

Geryl, P. 2011, Pole Shift and Pole Reversal in 2012, http://survive2012.com/ index.php/geryl-pole-shift.html (accessed 5 January 2011).

Godwin, J. 1994, The Theosophical Enlightenment, State University of New York Press, New York.

Hall, J. R., Schuyler, P. D., \& Trinh, S. 2000, Apocalypse Observed: Religious Movements and Violence in North America, Europe, and Japan, Routledge, London \& New York.

Hanegraaff, W. 1996, New Age Religion and Western Culture, E. J. Brill, Leiden.

Jenkins, J. M. 1998, Maya Cosmogenesis 2012, Bear \& Co., Santa Fe.

LeRoy, L. 1594, Of the Interchangeable Course, or Variety of Things in the Whole World, London.

Malinowski, B. 1954, Magic, Science and Religion, Doubleday, New York.

Plato 1931, Timaeus, transl. R. G. Bury, Harvard University Press, Cambridge MA.

Popper, K. 1957, The Poverty of Historicism, Routledge, London.

Popper, K. 1986, The Open Society and its Enemies (2 vols), revised edn, Routledge, London \& New York.

Robbins, T. \& Palmer, S. 1999, Millennium, Messiahs and Mayhem: Contemporary Apocalyptic Movements, Routledge, London.

Schwartz, H. 1980, The French Prophets: the History of a Millenarian Group in EighteenthCentury England, University of California Press, Berkeley.

Sky, E. 2011, How can we prepare for 2012? http://www. 13moon. com/prophecy\%20page.htm\#19 (accessed 4 January 2011).

Stocking, G. W. 1966, Franz Boas and the culture concept in historical perspective. American Anthropologist New Series 68(4), 867-882.

Stone, J. 2000, Expecting Armageddon: Essential Readings in Failed Prophecy, Routledge, London.

Thomas, K. 1980, Religion and the Decline of Magic, Peregrine Books, Harmondsworth.

Wessinger, C. 1997, Millenialism with and without the mayhem. In Robbins, T. \& Palmer, S. (eds), Millennium, Messiahs and Mayhem: Contemporary Apocalyptic Movements, Routledge, London, pp. 47-59. 